\title{
Beta-lactam and quinolone resistance markers in uropathogenic strains isolated from renal transplant recipients
}

\author{
Bianca-Simona Trușcă ${ }^{1}$, Irina Gheorghe ${ }^{1 *}$, Luminita Marutescu ${ }^{1,2}$, \\ Carmen Curutiu ${ }^{1,2}$, Florica Marinescu ${ }^{3}$,Camelia Mihaela Ghiță $\breve{4}^{4}$ Elvira Borcan ${ }^{4}$, \\ Liliana Țuică ${ }^{4}$, Vali Minciuna ${ }^{4}$, Hilda-Edit Gherghin ${ }^{4}$, \\ Mariana Carmen Chifiriuc ${ }^{1,2}$, Veronica Lazar ${ }^{1,2}$
}

\author{
1 Microbiology Department, Faculty of Biology, University of Bucharest, Bucharest, Romania \\ 2 Research Institute of the University of Bucharest-ICUB, Romania \\ 3 National Institute for Research and Development in Environmental Protection \\ 4 Fundeni Clinical Institute, Bucharest, Romania
}

\begin{abstract}
Our objectives were to investigate the extended-spectrum beta-lactamases (ESBLs) and carbapenemases (CR) genetic determinants and to assess the association between ESBL production and quinolone resistance in bacterial strains isolated from renal transplant recipients with urinary tract infections.

Material and methods: A number of 30 isolates were recovered from urine specimens of patients with renal transplant from October 2015 to March 2016. The isolates were analyzed for ESBL production using double disc synergy test and for CR production by the Hodge test. Phenotypically confirmed isolates were screened by PCR for the identification of ESBL, CR and fluoroquinolone resistance genes.

Results: The 30 clinical bacterial strains isolated from urinary tract infections in renal transplant recipients were identified as Klebsiella pneumoniae (17), Pseudomonas aeruginosa (7), Morganella morganii (2), Escherichia coli (2), Edwardsiella tarda (1) and Enterobacter cloacae (1). Out of them, 22 isolates were ESBL producers and 20 multi-drug resistant (MDR) (i.e., $13 \mathrm{~K}$. pneumoniae and 7 P. aeruginosa strains). More than half of the ESBL clinical strains $(14 / 22,63.63 \%)$ revealed at least one ESBL gene, the most frequent being bla $a_{C T X-M}$ type (18/22, $81.81 \%)$, either alone $(4 / 22,18.18 \%)$ or in combination with another ESBL gene (17/22, 77.27\%), followed by bla $_{T E M}(13 / 22,59.09 \%)$. The bla ${ }_{\text {OXA }}-48$ was present in 10 isolates $(33.33 \%)$. The most frequent association of ES$B L s$ and $C R$ genes $(5 / 14,35.71 \%)$ was revealed by bla $a_{C X X-M}-$ bla $_{T E M}-$ bla ${ }_{O X A}-48$, encountered particularly among K. pneumoniae isolates $(4 / 17,23.52 \%)$. The qnrB gene was identified in five strains, i.e. one P. aeruginosa ESBL isolate (expressing the bla $a_{C T X-M}$ gene) and four K. pneumoniae ESBL isolates (harboring the bla $a_{C T X-M}$ - bla ${ }_{T E M}$ genes combination).
\end{abstract}

*Corresponding author: Irina Gheorghe, University of Bucharest, Faculty of Biology Bucharest, Romania, e-mail: iryna_84@yahoo.com 
Conclusions: The uropathogenic strains isolated from renal transplant recipients exhibited high rates of MDR and beta-lactam resistance. The selective pressure exerted by quinolones could enable uropathogenic bacteria to acquire resistance to this class of antibiotics.

Keywords: renal transplant recipients, urinary tract infections ESBL producers, bla genes, quinolone resistance

Received: 10 ${ }^{\text {th }}$ April 2017; Accepted: $15^{\text {th }}$ October 2017; Published: $20^{\text {th }}$ October 2017

\section{Introduction}

Renal transplant recipients (RTRs) represent one of the categories of patients exhibiting the highest risk to develop UTIs, that could be one of the causes for allograft dysfunction. Additionally, the widespread use of antibiotics employed for prophylaxis and treatment of transplant recipients is leading to an increasing resistance to antibiotics among uropathogenic isolates $[1,2]$. Different studies reported that infections caused by beta-lactam resistant-K. pneumoniae in kidney transplant recipients were associated with higher mortality [3], recurrent UTIs being also reported [4,5]. Therefore, management strategies employing corrrect use of antibiotics and early diagnosis are essential for successful allograft and patient outcome. Our objective was to investigate the extended-spectrum beta-lactamases (ESBLs) and carbapenemases (CR) and to assess the association between beta-lactamases production and quinolone resistance in bacterial strains isolated from RTRs with urinary tract infections.

\section{Materials and Methods}

\section{Phenotypic characterization of bacterial isolates}

The isolates were obtained from urine specimens of RTR submitted to the Bacteriology Department of Fundeni Hospital, Bucharest, Romania, between September 2015 and March 2016. The urine cultures were performed in the Bacteriology Department of Fundeni Hospital, Bucharest, Romania. Microbial identification was performed using the Phoenix automated system (Becton Dickinson Company). The Clin- ical and Laboratory Standards Institute (CLSI, 2015) guidelines were employed for antibiotic susceptibility testing. ESBL production was determined by double-disk synergy test, while carbapenemase production was screened using the modified Hodge test [6]. A total of 30 bacterial isolates from urine samples of RTRs exhibiting increased antimicrobial resistance to beta-lactam antibiotics were selected.

\section{Molecular analysis of ESBL-positive strains}

ESBL producers were submitted to molecular characterization of the ESBL-encoding genes. Whole-cell DNAs were extracted using the alkaline extraction method. Simplex and multiplex PCR amplifications were performed for $b l a_{\mathrm{TEM}}[7], b l a_{\mathrm{SHV}}[8], b l a_{\mathrm{CTX}-\mathrm{M}}[9], b l a_{\mathrm{IMP}}$, bla $a_{\mathrm{VIM}}$, bla $_{\mathrm{NDM}}$, bla $a_{\mathrm{OXA}-48}[10]$ and bla $a_{\mathrm{PER}}[11]$, using a reaction mix of $20 \mu \mathrm{L}$ (PCR Master Mix 2x, Thermo Scientific), containing $1 \mu$ of bacterial DNA. The ESBL-producing clinical isolates exhibiting a fluoroquinolone resistance phenotype were further investigated for identification of fluoroquinolone resistance genetic determinants (gyrA, gyrB, parC, parE, qnrA, qnrB and qnrS) $[12,13]$. The amplification reactions were carried out in PCR thermal Corbett thermocycler under the following conditions: initial denaturation at $95^{\circ} \mathrm{C}$ for $10 \mathrm{~min}$, followed by 36 cycles of denaturation $\left(94^{\circ} \mathrm{C}\right.$ for $\left.30 \mathrm{sec}\right)$, annealing $\left(52^{\circ} \mathrm{C}\right.$ for $\left.40 \mathrm{sec}\right)$, extension $\left(72^{\circ}\right.$ for $\left.50 \mathrm{sec}\right)$ and a final extension step $\left(72^{\circ} \mathrm{C}\right.$ for $\left.5 \mathrm{~min}\right)$. DNA fragments were analyzed by electrophoresis in a $1 \%$ agarose gel, migrated at $100 \mathrm{~V}$ for $1 \mathrm{~h}$ in $1 \times$ TAE (40 mmol/L Tris-HCl [pH 8.3], 2 mmol/L acetate, $1 \mathrm{mmol} / \mathrm{L}$ EDTA) containing $0.05 \mathrm{mg} / \mathrm{L}$ ethidium bromide [10]. 


\section{Results}

\section{Antimicrobial susceptibility profiles}

Among the 30 clinical bacterial strains isolated from urine samples of RTRs, 17 Klebsiella pneumoniae, 7 Pseudomonas aeruginosa, 2 Morganella morganii, 2 Escherichia coli, 1 Edwardsiella tarda and 1 Enterobacter cloacae were identified. Antimicrobial susceptibility test results showed that 20 isolates were MDR (all $P$. aeruginosa strains and 13 strains of $K$. pneumoniae), exhibiting resistance to cephalosporins (third [ceftazidime] and fourth generation [cefepime], carbapenems (imipenem and meropenem), and quinolones (ciprofloxacin, levofloxacin) and 22 were ESBL-producers. Of these, 14 were $K$. pneumoniae, four $P$. aerugi$n o s a$, two M. morganii, one E. coli and one $E$. tarda. Furthermore, all ESBL producers were resistant to trimetoprim-sulphamethoxazole and gentamicin (Figure 1). A total of $13 \mathrm{~K}$. pneumoniae isolates were carbapenemase producers, exhibiting also resistance to cephalosporins (third and fourth generation), quinolones (ofloxacin, levofloxacin, ciprofloxacin), monobactams (aztreonam), trimetoprim-sulphamethoxazole and gentamicin. A higher susceptibility rate was observed only in case of amikacin (Table 1 and 2).

Table 1. In vitro antimicrobial susceptibility of clinical strains isolated from urine samples of renal transplant recipients.

\begin{tabular}{lcc}
\hline Antimicrobial agent & $\begin{array}{c}\text { No. } \\
\text { isolates } \\
\text { tested }\end{array}$ & $\begin{array}{c}\text { No. } \\
\text { susceptible } \\
\text { isolates }\end{array}$ \\
\hline Amoxicillin/ clavulanate & 23 & 0 \\
\hline Cefotaxime & 23 & 0 \\
\hline Ceftazidime & 30 & 0 \\
\hline Cefepime & 30 & 0 \\
\hline Piperacillin/Tazobactam & 30 & 10 \\
\hline Ertapenem & 23 & 3 \\
\hline Meropenem & 30 & 16 \\
\hline Imipenem & 30 & 18 \\
\hline Aztreonam & 30 & 0 \\
\hline Ciprofloxacin & 30 & 0 \\
\hline Norfloxacin & 30 & 4 \\
\hline Levofloxacin & 30 & 0 \\
\hline Amikacin & 30 & 30 \\
\hline Gentamicin & 30 & 8 \\
\hline Trimethoprim/Sulpha- & 23 & 0 \\
metoxazole (TMP/SXT) & & 3 \\
\hline Tigecycline & 23 & 3 \\
\hline
\end{tabular}

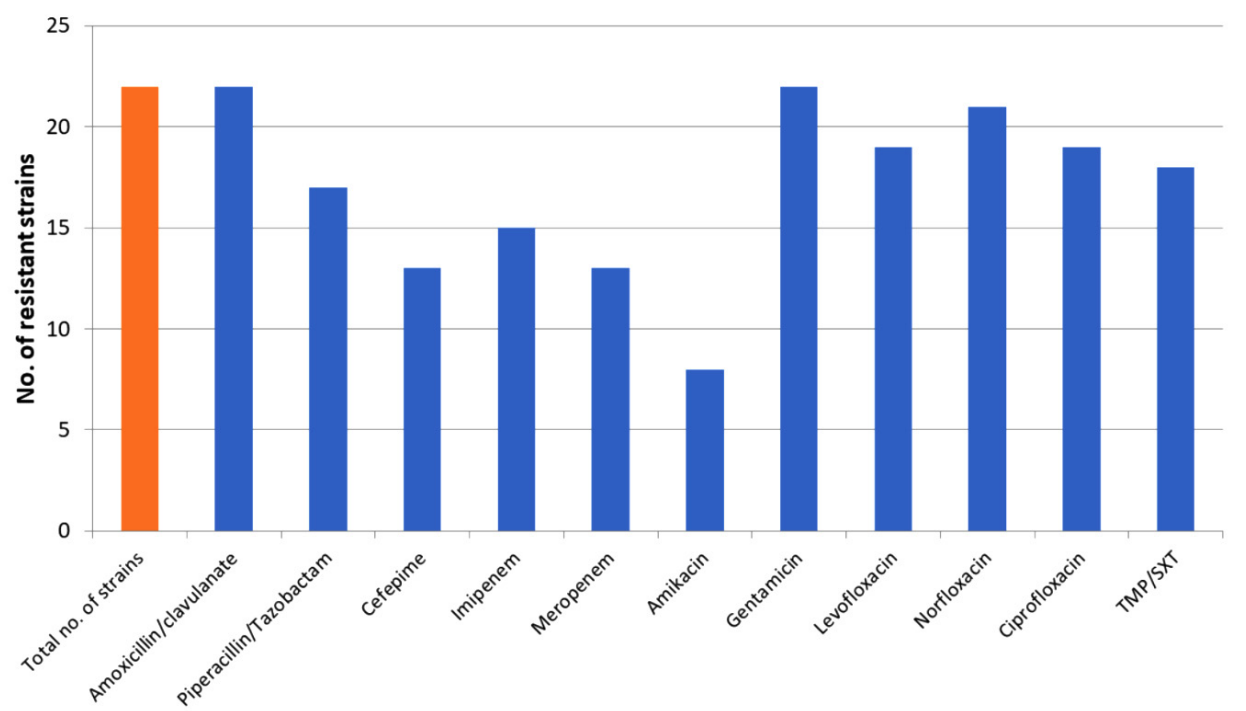

Figure 1. Antimicrobial resistance profiles for the 22 ESBL-producing urinary isolates. 
Table 2. Antimicrobial susceptibility (\%) of ESBL-producing isolates isolated from urine samples of renal transplant recipients

\begin{tabular}{|c|c|c|c|c|c|c|c|c|c|c|c|c|c|c|c|c|c|c|}
\hline \multirow{3}{*}{ Antimicrobials } & \multicolumn{4}{|c|}{ Total (30) } & \multicolumn{4}{|c|}{$\begin{array}{l}\text { K. pneumoniae } \\
\text { spp. (17) }\end{array}$} & \multirow{2}{*}{\multicolumn{2}{|c|}{$\begin{array}{c}M . \\
\text { morganii } \\
(2) \\
\text { ESBL } \\
(2) \\
\end{array}$}} & \multirow{2}{*}{\multicolumn{2}{|c|}{$\begin{array}{c}\text { E. coli } \\
(2)\end{array}$}} & \multirow{2}{*}{\multicolumn{2}{|c|}{$\begin{array}{c}\text { E. tarda } \\
\text { (1) } \\
\text { ESBL } \\
(1) \\
\end{array}$}} & \multirow{2}{*}{\multicolumn{2}{|c|}{$\begin{array}{c}E . \\
\text { cloacae } \\
(1) \\
\text { ESBL } \\
(1)\end{array}$}} & \multirow{2}{*}{\multicolumn{2}{|c|}{$\begin{array}{c}\text { P. aeru- } \\
\text { ginosa } \\
\text { (7) } \\
\text { MDR } \\
(7) \\
\end{array}$}} \\
\hline & \multicolumn{2}{|c|}{$\begin{array}{l}\text { ESBL } \\
(10)\end{array}$} & \multicolumn{2}{|c|}{$\begin{array}{c}\text { MDR } \\
(20)\end{array}$} & \multicolumn{2}{|c|}{$\begin{array}{c}\text { ESBL } \\
(4)\end{array}$} & \multicolumn{2}{|c|}{$\begin{array}{c}\text { MDR } \\
(13)\end{array}$} & & & & & & & & & & \\
\hline & $\mathrm{R}$ & $\mathrm{S}$ & $\mathrm{R}$ & $\mathrm{S}$ & $\mathrm{R}$ & $\mathrm{S}$ & $\mathrm{R}$ & $\mathrm{S}$ & $\mathrm{R}$ & $\mathrm{S}$ & $\mathrm{R}$ & $\mathrm{S}$ & $\mathrm{R}$ & $\mathrm{S}$ & $\mathrm{R}$ & $\mathrm{S}$ & $\mathrm{R}$ & $\mathrm{S}$ \\
\hline $\begin{array}{l}\text { Amoxicillin/ } \\
\text { clavulanate }\end{array}$ & 10 & 0 & 13 & 0 & 4 & 0 & 13 & 0 & 2 & 0 & 2 & 0 & 1 & 0 & 1 & 0 & $\mathrm{nt}$ & $\mathrm{nt}$ \\
\hline Cefotaxime & 10 & 0 & 20 & 0 & 4 & 0 & 13 & 0 & 2 & 0 & 2 & 0 & 1 & 0 & 1 & 0 & nt & $\mathrm{nt}$ \\
\hline Ceftazidime & 10 & 0 & 20 & 0 & 4 & 0 & 13 & 0 & 2 & 0 & 2 & 0 & 1 & 0 & 1 & 0 & 7 & 0 \\
\hline Cefepime & 4 & 0 & 20 & 0 & - & - & 13 & 0 & 1 & 0 & 2 & 0 & 1 & 0 & $\mathrm{nt}$ & $\mathrm{nt}$ & 7 & 0 \\
\hline Pip/Tazo & 6 & 4 & 18 & 2 & 2 & 2 & 13 & 0 & 2 & 0 & 1 & 1 & 0 & 1 & 1 & 0 & 5 & 2 \\
\hline Ertapenem & 2 & 7 & 19 & 1 & 2 & 2 & 12 & 1 & 0 & 1 & 0 & 2 & 0 & 1 & 0 & 1 & $\mathrm{nt}$ & $\mathrm{nt}$ \\
\hline Meropenem & 1 & 8 & 20 & 0 & 1 & 2 & 13 & 0 & 0 & 2 & 0 & 2 & 0 & 1 & 0 & 1 & 7 & 0 \\
\hline Imipenem & 1 & 9 & 20 & 0 & 0 & 4 & 12 & 1 & 1 & 1 & 0 & 2 & 0 & 1 & 0 & 1 & 7 & 0 \\
\hline Aztreonam & $\mathrm{nt}$ & $\mathrm{nt}$ & 9 & $\mathrm{nt}$ & $\mathrm{nt}$ & $\mathrm{nt}$ & 9 & $\mathrm{nt}$ & $\mathrm{nt}$ & $\mathrm{nt}$ & $\mathrm{nt}$ & $\mathrm{nt}$ & $\mathrm{nt}$ & $\mathrm{nt}$ & $\mathrm{nt}$ & $\mathrm{nt}$ & $\mathrm{nt}$ & $\mathrm{nt}$ \\
\hline Ciprofloxacin & 6 & 0 & 20 & 0 & 2 & 0 & 13 & 0 & $\mathrm{nt}$ & $\mathrm{nt}$ & 2 & 0 & 1 & 0 & 1 & 0 & 7 & 0 \\
\hline Norfloxacin & 8 & 2 & 20 & 0 & 3 & 1 & 13 & 0 & 1 & 1 & 2 & & 1 & 0 & 1 & 0 & 7 & 0 \\
\hline Levofloxacin & 6 & 2 & 20 & 0 & 2 & 0 & 13 & 0 & 0 & 2 & 2 & 0 & 1 & 0 & 1 & 0 & 7 & 0 \\
\hline Amikacin & 0 & 9 & 5 & 13 & 0 & 3 & 0 & 13 & 0 & 2 & 0 & 2 & 0 & 1 & 0 & 1 & 7 & 0 \\
\hline Gentamicin & 5 & 4 & 20 & 0 & 3 & 1 & 13 & 0 & 0 & 1 & 1 & 1 & 0 & 1 & 1 & 0 & 7 & 0 \\
\hline TMP/SXT & 9 & 0 & 13 & 0 & 4 & 0 & 13 & 0 & 1 & 0 & 2 & 0 & 1 & 0 & 1 & 0 & $\mathrm{nt}$ & $\mathrm{nt}$ \\
\hline Tigecycline & 0 & 0 & 2 & 11 & $\mathrm{nt}$ & $\mathrm{nt}$ & 2 & 11 & $\mathrm{nt}$ & $\mathrm{nt}$ & $\mathrm{nt}$ & nt & $\mathrm{nt}$ & $\mathrm{nt}$ & $\mathrm{nt}$ & $\mathrm{nt}$ & $\mathrm{nt}$ & $\mathrm{nt}$ \\
\hline
\end{tabular}

\section{Screeening of ESBL, CR and quinolone resistance genes}

CTX-M enzymes were the majority of the revealed ESBLs (18/22), alone (4/22) or in combination with another ESBL gene (17/22) followed by TEM (13/22). The OXA-48 carbapenemase was present in 10 isolates. More than half of the ESBL clinical strains (14/22,) revealed at least one ESBL gene. Among the K. pneumoniae isolates, bla ${ }_{\text {СТХ-M }}-b l a_{\text {TЕM }}(6 / 17,35.29 \%)$ was the most frequent association, followed by the association between 2 ESBLs and one CRG (carbapenem resistance gene) [ $b l a_{\text {CTX-M- }}$ bla $a_{\text {TEM - }}$ blaOXA-48 $(4 / 17,23.52 \%)]$ and by one ESBL and one CRG $\left[b l a_{\text {СТХ-M- }} b l a_{\text {OXA-48 }}(2 / 17,11.76 \%)\right]$. A low number of the studied strains expressed only one $\beta$-lactam resistance gene, i.e.: bla ${ }_{\text {СТХ-м }}(13.33 \%)$, bla $_{\text {TEM }}(6.66 \%)$ and bla $a_{\text {OXA-48 }}(6.66 \%)$ (Table 3).

Among the quinolone resistant clinical strains the PMQR qnrB gene was identified in one $P$. aeruginosa isolate also harboring $b l a_{\text {СТХ-M }}$ and in four K. pneumoniae ESBL-positive isolates (harboring the $b l a_{\text {CTX-M- }} b l a_{\text {TEM }}$ gene combination) (Table 3).

\section{Discussion}

RTRs are reported to exhibit the highest incidence of UTIs [14,15]. Although third generation cephalosporins [16] and trimethoprim-sulfamethoxazole have been shown to prevent the occurence of UTI in the post-transplantation period [17], however, chemoprophylaxis has led to the selection of resistance, including the emergence of ESBL producing isolates [18].

$K$. pneumoniae and E. coli isolates are according to ECDC (European Centre for Disease and Control) the most frequent etiological agents of UTIs. The latest data are indicating that Romania is one of the UE countries with 
Table 3. Distribution of ESBLs, CRGs and QNRBs among clinical strains isolated from urine samples of renal transplant recipients

\begin{tabular}{|c|c|c|c|c|c|c|}
\hline \multirow[t]{2}{*}{ Species } & \multirow[t]{2}{*}{$\begin{array}{l}\text { Number of } \\
\text { isolates }\end{array}$} & \multicolumn{4}{|c|}{$\begin{array}{l}\text { Type of ESBL and CR } \\
\text { (number of isolates) }\end{array}$} & \multirow{2}{*}{$\begin{array}{c}\begin{array}{c}\text { QRDRs } \\
\text { (number of } \\
\text { isolates) }\end{array} \\
\text { QNRB }\end{array}$} \\
\hline & & CTX-M & TEM & OXA-48 & $\begin{array}{c}\text { ESBLs and Carbapenemases } \\
\text { (different associations) }\end{array}$ & \\
\hline K. pneumoniae & 17 & 1 & & 1 & $\begin{array}{c}\text { CTX-M - TEM (6) } \\
\text { CTX-M - OXA-48 (2) } \\
\text { CTX-M - TEM - OXA-48 (4) }\end{array}$ & 4 \\
\hline M. morganii & 2 & 1 & 1 & & & \\
\hline E. coli & 2 & 1 & & & & \\
\hline E. tarda & 1 & 1 & & & & \\
\hline $\begin{array}{l}\text { Enterobacter } \\
\text { cloacae }\end{array}$ & 1 & & & & & \\
\hline P. aeruginosa & 7 & & 1 & 1 & $\begin{array}{c}\text { CTX-M (1) } \\
\text { CTX-M - TEM (1) }\end{array}$ & 1 \\
\hline $\begin{array}{l}\text { Number of } \\
\text { strains (\%) }\end{array}$ & 30 & $\begin{array}{c}4 \\
(13.33 \%)\end{array}$ & $\begin{array}{c}2 \\
(6.66 \%) \\
\end{array}$ & $\begin{array}{c}2 \\
(6.66 \%)\end{array}$ & $\begin{array}{c}14 \\
(47.66 \%)\end{array}$ & $\begin{array}{c}5 \\
16.66\end{array}$ \\
\hline
\end{tabular}

the highest resistance rates of $K$. pneumoniae to third generation cephalosporins (65-83\%), fluoroquinolones (55-77\%), aminoglycosides (48$60 \%$ ), carbapenems (20-30\%) and MDR (4556\%) (https://ecdc.europa.eu/sites/portal/files/ media/en/publications/Publications/antimicrobial-resistance-europe-2015.pdf). In a recent Romanian study performed in an infectious disease hospital, the resistance rates to the third generation cephalosporins (cefotaxime) were of 39\% for Klebsiella spp. and 12\% for E. coli. Anon-interventional, retrospective study performed in "Prof. Dr. Matei Bals" National Institute of Infectious Diseases in Bucharest, revealed lower resistance rates of $K$. pneumoniae blood isolates to fluoroquinolones, aminoglycosides, third generation cephalosporins, carbapenems, and MDR, as compared to those reported by our country to EARS-Net [19].

The present study was carried out in a healthcare setting for kidney transplant in Bucharest, Romania. Over a six-month period (September 2015 to March 2016) a total of 30 clinical isolates from urine samples of RTR exhibiting in- creased antimicrobial resistance were selected. Phenotypic and molecular characterization of the clinical isolates revealed that $22(73.33 \%)$ were ESBL producers, i.e.: K. pneumoniae (14), P. aeruginosa (4), M. morganii (2), E. coli (1) and E. tarda (1). The findings of our study are in accordance with several other studies that are describing an elevated frequency of ESBL infections among RTRs that received prophylactic antibiotic treatment [20, 21, 4, 22, 23]. We found that all of them exhibited resistance to third generation cephalosporins, that it is reported to be linked to the emergence of MDR isolates [24]. All ESBL producers were also resistant to gentamicin and trimethoprim-sulphamethoxazole, as reported by other authors [25]. Trimethoprim-sulphamethoxazole resistance is most frequently encoded by plasmids, including some coexpressing ESBLs. The increased proportion of ESBL simultaneous with resistance to other classes of antibiotics, constitutes a major therapeutic problem for infections produced by resistant K. pneumoniae or E.coli isolates, relying on carbapenems, as last therepeutic option. 
However, this could contribute to the emergence of carbapenem resistant bacteria, as also confirmed by our study in which a very high number of $K$. pneumoniae isolates displayed carbapenem resistance (13). In 2014, Romania reported 81 carbapenemase resistant $K$. pneumoniae isolates (31.5\%), the number decreasing in 2015 to 67 isolates.

Our molecular assays showed that the majority of the ESBL-producing strains harbored a bla $a_{\text {СTX-M }}$ gene alone, but also in association with another ESBL or CRG, followed by bla ${ }_{\mathrm{TEM}}$. Approximatively half of the clinical strains $(14 / 22 \%)$ expressed more than one beta-lactam resistance gene, the most frequent being the association $b l a_{\text {CTX-M- }} b l a_{\text {TEM - }} b l a_{\text {OXA-48, }}$ particularly among $K$. pneumoniae strains. These findings are in accordance with previous investigations performed in Romania. The first confirmed cases of OXA-48 - NDM-1 producing Enterobacteriaceae, mostly K. pneumoniae, were detected in 2012 [26]. A more recent study carried out on clinical strains isolated from patients hospitalized in ICUs in southern Romania revealed a high prevalence and a wide diversity of ESBL genes ( $b l a_{\text {CTX-Mlike, }} b l a_{\text {TEMlike }}$ and $b l a_{\text {SHVlike }}$ in Enterobacteriaceae isolates and $b l a_{\mathrm{GESlike}}, b l a_{\mathrm{SHVlike}}$ and bla $_{\mathrm{VEBlike}}$ in nonfermenting rods ( $P$. aeruginosa and Acinetobacter baumannii) [27]. Also, the CRGs bla $a_{\text {OXA-48 }}, b l a_{\mathrm{NDM}-1}$ and $b l a_{\mathrm{OXA}-181}$ in Enterobacteriaceae strains isolated in northern

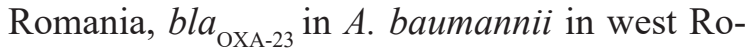
mania, and bla ${ }_{\mathrm{VIM}-2}$ in P.aeruginosa in north-east Romania have been reported [28].

Another pathogen frequently involved in the etiology of UTIs in RTRs is MDR $P$. aerugino$s a$ [29]. Our results indicated that $23.33 \%(7 / 30)$ of $P$. aeruginosa exhibited a MDR phenotype and of these, $28.57 \%(2 / 7)$ were carrying ESBL genes. In $P$. aeruginosa isolates, the ESBLs are still less frequently detected; the most common are OXA derivatives (class D $\beta$-lactamases), PER enzymes [30] and VEB enzymes (class
A $\beta$-lactamases) [31]. The ESBL coding genes combination $b l a_{\text {СТХ-M }}-b l a_{\text {TEM }}$ was also detected in the analysed $P$. aeruginosa isolates. These findings are suggesting the possible exchange of resistance determinants between Enterobacteriaceae and non-Enterobacteriaceae isolates.

Significantly elevated trends with regard to the national percentages of fluoroquinolone resistant isolates were reported by Romania for the period 2012-2015 (www.ecdc.europa.eu). In our study all investigated strains were resistant to fluoroquinolone. These antimicrobials are employed in the treatment of infections caused by uropathogens resistant to most $\beta$-lactams, particularly the extended-spectrum cephalosporins and, more recently, the carbapenems. However, an increasing percentage of Klebsiella sp. strains developed resistance to fluoroquinolones [19]. In another study, the phenotypic analysis of 61 $P$. aeruginosa isolates from a laboratory hospital from north-east Romania revealed a resistance level of $17.69 \%$.

The high incidence of ESBLs isolates with combined resistance to fluoroquinolones has become an important concern nowadays [32]. EARS-Net reported in 2015 that among the $K$. pneumoniae resistant isolates, combined resistance to fluoroquinolones, third-generation cephalosporins and aminoglycosides was the most prevalent phenotype (https://ecdc.europa. $\mathrm{eu} /$ sites/portal/files/media/en/publications/Publications/antimicrobial-resistance-europe-2015. pdf). In Turkish hospitals, a dramatic increase of resistance rates to quinolones among uropathogenic E.coli, from $30.4 \%$ in 2003 , $41.3 \%$ in 2007 , to $59.4 \%$ in 2012 in RTRs was reported [33]. We found that all bacterial strains with ESBL phenotype exhibited also a fluoroquinolone-resistance phenotype.

The coexpression of the qnr gene and efflux pumps on plasmids carrying ESBLs may encourage the development of gyrA-and parC-mediated fluoroquinolone resistance and emergence 
of highly resistant strains [34]. In our study the PMQR $q n r \mathrm{~B}$ gene, was identified in five $(16.16 \%)$ clinical strains, i.e.: one $P$. aeruginosa ESBL isolate (expressing the bla $a_{\text {СТХ-м }}$ gene) and four $K$. pneumoniae ESBL isolates (harboring the association between 2 ESBLs genes $\left(b l a_{\mathrm{C}}\right.$ TX-M $\left.-b l a_{\mathrm{TEM}}\right)$. Co-resistance to fluoroquinolones, which is more commonly due to chromosomal mutations in genes coding for DNA gyrase rather than plasmids carrying genes for low-level resistance, is more likely to have been acquired independently of a plasmid-borne ESBL gene. One possible explanation for the significant co-resistance among ESBL-producing isolates is the presence of multiple plasmid-borne resistance loci [35]. Until now the efflux-based resistance mechanisms has never been documented in ESBL-bearing plasmids. Lagacé-Wiens reported that $q n r$-mediated quinolone resistance remains extremely rare in ESBL-bearing plasmids and has not yet been reported in Canadian E. coli isolates. Molecular characterization of a collection of Romanian isolates of ciprofloxacin-resistant $E$. coli isolates from human extraintestinal specimens showed that they were carrying double mutations in the QRDR of gyrA. A high percentage of them $(69 \%)$ possessed bla $a_{\text {CTX-like }}$ genes, and with one exception, all were ESBL producers [36].

Considering the recent studies involving monitoring, antimicrobial resistance rates have been shown to significantly increase, threatening the available treatment options for common infections [37-39]. In case of RTRs, prolonged hospitalization, broad-spectrum antimicrobial treatment, the use of urinaty catheters and the renal replacement therapy are all contributing to the occurence of MDR bacteria.

To our knowledge this report represents the first study regarding the antibiotic resistance markers in uropathogenic strains isolated from RTRs in Romania. In our study, very high rates of resistance have been observed in the bacte- ria isolated RTRs, more than $70 \%$ of the bacteria carring a $\beta$-lactamase genes that virtually could reach any Gram-negative bacterium and become a major threat in the future. Of major importance is the detection of a high number of K. pneumoniae isolates resistant to carbapenems (76.47\%), the last-treatment option for severe community and hospital acquired infections. Moreover, all ESBL urinary isolates were fluoroquinolone-resistant. Molecular investigations revelead the presence of quinolone resistance genetic markers in $36.36 \%$ of ESBL strains. The combined resistance of uropathogenic isolates to fluoroquinolones and extended-spectrum cephalosporins could lead to limitations to available treatment options for UTIs in RTRs.

\section{Acknowledgements}

The financial support of the research projects Human Resources PN-II-RU-TE-2014-4-2037 and PN-III-P2-2.1-BG-2016-0369 is gratefully acknowledged.

\section{Abreviations}

RTR $=$ renal transplant recipients

MDROs = multi-drug resistant organisms

MDR $=$ multi drug resistant

ESBLs $=$ extended-spectrum beta-lactamases

UTIs $=$ urinary tract infections

CLSI $=$ Clinical and Laboratory Standards Institute

DDST $=$ double-disk synergy test

$\mathrm{PMQR}=$ plasmid-mediated quinolone resistance QRDRs = quinolone resistance-determining regions

$\mathrm{CRE}=$ carbapenem resistant Enterobacteriaceae $\mathrm{CR}=$ carbapenemases

$\mathrm{CRG}=$ carbapenem resistance genes 


\section{References}

1. Kritikos A, Manuel O. Bloodstream infections after solid-organ transplantation. Virulence. 2016;7(3):32940. DOI: $10.1080 / 21505594.2016 .1139279$

2. Parasuraman R, Julian K, the AST Infectious Diseases Community of Practice. Urinary Tract Infections in Solid Organ Transplantation. Am J Transplant. 2013;13:327-36. DOI: 10.1111/ajt.12124

3. Freire MP, Antonopoulos IM, Piovesan AC, Moura ML, de Paula FJ, Spadão F, et al. Amikacin prophylaxis and risk factors for surgical site infection after kidney transplantation. Transplantation. 2015 Mar;99(3):5217. DOI: 10.1097/TP.0000000000000381

4. Vidal E, Torre-Cisneros J, Blanes M, Montejo M, Cervera C, Aguado JM, et al. Spanish Network for Research in Infectious Diseases (REIPI). Bacterial urinary tract infection after solid organ transplantation in the RESITRA cohort. Transpl Infect Dis. 2012 Dec;14(6):595603.DOI: 10.1111/j.1399-3062.2012.00744.x

5. Pinheiro HS, Mituiassu AM, Carminatti M, Braga AM, Bastos MG. Urinary tract infection caused by extended-spectrum beta-lactamase-producing bacteria in kidney transplant patients. Transplant Proc. 2010;42(2):486-7. DOI: 10.1016/j.transproceed.2010.02.002

6. CLSI. Performance Standards for Antimicrobial Susceptibility Testing; Twenty-Fifth Informational Supplement. CLSI document M100-S25. Wayne, PA: Clinical and Laboratory Standards Institute; 2015.

7. Efrekar RF, Hosseini-Mazinani SM, Ghandili S, Hamraz M, Zamani S. PCR detection of plasmid mediated TEM, SHV and AmpC $\beta$-lactamases in community and nosocomial urinary isolates of Escherichia coli. Iranian J Biotech. 2005;3(1):48-54.

8. Naas T, Philippon L, Poirel L, Ronco E, Nordmann P. An SHV-derived extended spectrum $\beta$-lactamase in Pseudomonas aeruginosa. Antimicrob Agents Chemother. 1999;43:1281-4.

9. Israil A, Chifiriuc C, Palade G, Cotar A. Clinical and bacteriological aspects of bacterial infections associated to abdominal surgical emergencies. Ars Docenti Publ. House. 2013:150.

10. Poirel L, Walsh TR, Cuvillier V, Nordmann P. Multiplex PCR for detection of acquired carbapenemase genes. Diagn Microbiol Infect Dis. 2011;70(1):11923. DOI: 10.1016/j.diagmicrobio.2010.12.002

11. Jiang X, Ni Y, Jiang Y, Yuan F, Han L, Li M. Outbreak of infection caused by Enterobacter cloacae producing the novel VEB-3 beta-lactamase in China. J Clin Microbiol. 2005;43:826-31. DOI: 10.1128/JCM.43.2.826831.2005

12. Agnello M, Wong-Beringer A. Differentiation in quinolone resistance by virulence genotype in Pseudomonas aeruginosa. PLoS ONE. 2012;7(8):e42973. DOI: 10.1371/journal.pone.0042973
13. Cattoir V, Poirel L, Rotimi V, Soussy CJ, Nordmann P. Multiplex PCR for detection of plasmid-mediated quinolone resistance qnr genes in ESBL-producing enterobacterial isolates. J Antimicrob Chemother. 2007;60(2): 394-397. DOI: 10.1093/jac/dkm204

14. Chuang P, Parikh CR, Langone A. Urinary tract infections after renal transplantation: a retrospective review at two US transplant centers. Clin Transplant. 2005;19: 230-5. DOI: 10.1111/j.1399-0012.2005.00327.x

15. de Souza RM, Olsburgh J. Urinary tract infection in the renal transplant patient. Nat Clin Pract Nephrol. 2008;4:252-64. DOI: 10.1038/ncpneph0781

16. Naber KG, Bergman B, Bishop MC, Bjerklund-Johansen TE, Botto H, Lobel B, et al. Urinary Tract Infection (UTI) Working Group of the Health Care Office (HCO) of the European Association of Urology (EAU). EAU guidelines for the management of urinary and male genital tract infections. Urinary Tract Infection (UTI) Working Group of the Health Care Office (HCO) of the European Association of Urology (EAU). EurUrol. 2001 Nov;40(5):576-88. DOI: 10.1159/000049840

17. Fox BC, Sollinger HW, Belzer FO, Maki DG. A prospective, randomized, double-blind study of trimethoprim-sulfamethoxazole for prophylaxis of infection in renal transplantation: clinical efficacy, absorption of trimethoprim-sulfamethoxazole, effects on the microflora, and the cost-benefit of prophylaxis. Am J Med. 1990 Sep;89(3):255-74. DOI: 10.1016/00029343(90)90337-D

18. Säemann M, Hörl WH. Review Urinary tract infection in renal transplant recipients. Eur J Clin Invest. 2008;38 Suppl 2:58-65. DOI: 10.1111/j.13652362.2008.02014.x

19. Gavriliu L, Benea O, Benea S. Antimicrobial resistance temporal trend of Klebsiella pneumoniae isolated from blood . Journal of Medicine and Life. 2016; 9(4):41923.

20. Lautenbach E, Patel JB, Bilker WB, Edelstein PH, Fishman NO Extended-spectrum beta-lactamase-producing Escherichia coli and Klebsiella pneumoniae: risk factors for infection and impact of resistance on outcomes. Clin Infect Dis. 2001;32(8):1162-71. DOI: 10.1086/319757

21. Linares L, Cervera C, Cofán F, Lizaso D, Marco F, Ricart MJ, et al. Risk factors for infection with extended-spectrum and AmpC beta-lactamase-producing gram-negative rods in renal transplantation. Am J Transplant. 2008 May;8(5):1000-5. DOI: 10.1111/j.16006143.2008.02197.x

22. Valera B, Gentil MA, Cabello V, Fijo J, Cordero E, Cisneros JM. Epidemiology of urinary infections in renal transplant recipients. Transplant Proc. 2006;38(8):24145. DOI: $10.1016 /$ j.transproceed.2006.08.018

23. Johnson JR, Johnston B, Clabots C, Kuskowski MA, Pendyala S, DebRoy C, et al. Escherichia coli Sequence 
Type ST131 as an Emerging Fluoroquinolone-Resistant Uropathogen among Renal Transplant Recipients. Antimicrobial Antimicrob Agents Chemother. 2010;54(1):546-50.DOI: 10.1128/AAC.01089-09

24. Choi SU, Lee JH, Oh CK, Shin GT, Kim H, Kim SJ, Kim SI. Clinical significance of prophylactic antibiotics in renal transplantation. Transplant Proc 2013;45(4):13925. DOI: $10.1016 /$ j.transproceed.2012.10.059

25. Kader AA, Kumar A. Prevalence and antimicrobial susceptibility of extended-spectrum beta-lactamase-producing Escherichia coli and Klebsiella pneumoniae in a general hospital. Ann Saudi Med. 2005;25(3):239-42.

26. Székely E, Damjanova I, Jánvári L, Vas KE, Molnar S, Bilca DV, Löriczi LK, Tóth A. First description of bla(NDM-1), bla(OXA-48), bla(OXA-181) producing Enterobacteriaceae strains in Romania. Int $\mathrm{J}$ Med Microbiol. 2013;303(8):697-700. DOI: 10.1016/j. ijmm.2013.10.001

27. Czobor I, Gheorghe I, Banu O, Velican A, Lazăr V, Mihăescu G, Chifiriuc M.C. ESBL genes in Multi Drug Resistant Gram negative strains isolated in a one year survey from an Intensive Care Unit in Bucharest, Romania. Roumanian Biotechnological Letters. 2014;19(4):9553-6.

28. Mereuță AI, Bădescu AC, Dorneanu OS, Iancu LS, Tuchiluş CG. Spread of VIM-2 metallo-beta-lactamase in Pseudomonas aeruginosa and Acinetobacter baumannii clinical isolates from Iași, România. Rev Romana Med Lab. 2013; 21(4): 389-396. DOI: 10.2478/ rrlm-2013-0035

29. Bodro M, Sanclemente G, Lipperheide I, Allali M, Marco F, Bosch J, et al. Impact of antibiotic resistance on the development of recurrent and relapsing symptomatic urinary tract infection in kidney recipients. Am J Transplant. 2015 Apr;15(4):1021-7. DOI: 10.1111/ ajt. 13075

30. Vahaboglu H, Oztürk R, Aygün G, Coşkunkan F, Yaman A, Kaygusuz A, et al. Widespread detection of PER-1-type extended-spectrum beta-lactamases among nosocomial Acinetobacter and Pseudomonas aeruginosa isolates in Turkey: a nationwide multicenter study.
Antimicrob Agents Chemother. 1997;41(10):2265-9.

31. Girlich D, Naas T, Leelaporn A, Poirel L, Fennewald M, Nordmann P. Nosocomial spread of the integron-located veb-1-like cassette encoding an extended-pectrum beta-lactamase in Pseudomonas aeruginosa in Thailand. Clin Infect Dis. 2002; 34(5):603-11. DOI: $10.1086 / 338786$

32. Bouchillon S, Hoban DJ, Badal R, Hawser S. Fluoroquinolone Resistance Among Gram-Negative Urinary Tract Pathogens: Global Smart Program Results, 2009-2010. Open Microbiol J. 2012;6:74-78. DOI: 10.2174/1874285801206010074

33. Azap Ö, Togan T,Yesilkaya A, Arslan H, Haberal M. Antimicrobial susceptibilities of uropathogen Escherichia coli in renal transplant recipients: dramatic increase in ciprofloxacin resistance.Transplant Proc. 2013;45(3):956 - 957. DOI: 10.1016/j.transproceed.2013.03.006

34. Lagacé-Wiens PR, Nichol KA, Nicolle LE, DeCorby MR, McCracken M, Alfa MJ, Zhanel GG. ESBL genotypes in fluoroquinolone-resistant and fluoroquinolone-susceptible ESBL-producing Escherichia coli urinary isolates in Manitoba. Can J Infect Dis Med Microbiol. 2007;18(2):133-7. DOI: 10.1155/2007/848194

35. Jacoby GA, Sutton L. Properties of plasmids responsible for production of extended-spectrum beta-lactamases. Antimicrob Agents Chemother. 1991;35(1):1649. DOI: 10.1128/AAC.35.1.164

36. Usein CR, Tatu-Chiţoiu D, Nica M, Ciontea SA, Palade AM, Condei M, Damian M. Characteristics of Romanian fluoroquinolone-resistant human clinical Escherichia coli isolates. Roum Arch Microbiol Immunol. 2008;67(1-2):23-9.

37. https://ecdc.europa.eu/sites/portal/files/media/en/ publications/Publications/antimicrobial-resistance-europe-2015.pdf.

38. www.ecdc.europa.eu. Antimicrobial resistance surveillance in Europe 2015.

39. https://ecdc.europa.eu/sites/portal/files/media/en/ publications/Publications/antimicrobial-resistance-europe-2015.pdf. 